\title{
PERAN SIKAP DALAM MEMEDIASI PENGARUH WEBSITE LAYOUT DESIGN TERHADAP NIAT BELI KEMBALI
}

\author{
Putu Wisnawan Dharma Sunu ${ }^{1}$ \\ Putu Yudi Setiawan ${ }^{2}$ \\ ${ }^{1,2}$ Fakultas Ekonomi dan Bisnis Universitas Udayana (Unud), Bali, Indonesia \\ email: wisnu.indonesian@gmail.com
}

\begin{abstract}
ABSTRAK
Tujuan penelitian ini adalah untuk mengetahui hubungan antar variabel website layout design, sikap dan niat beli kembali konsumen Penelitian ini dilakukan pada pelanggan Lazada.co.id di Bali. Ukuran sampel yang diambil sebanyak 90 responden, dengan metode non-probability sampling. Pengumpulan data dilakukan melalui penyebaran kuesioner. Teknik analisis data yang digunakan adalah PLS serta uji sobel. Hasil analisis menemukan bahwa hubungan secara langsung antar variabel website layout design, sikap dan niat membeli kembali memiliki hubungan positif signifikan. Sedangkan secara tidak langsung, sikap mampu memediasi website layout design dan niat membeli kembali. Hal ini menunjukkan bahwa niat membeli kembali konsumen Lazada.co.id di Bali akan meningkat jika sikap positif meningkat yang dipengaruhi oleh baiknya tampilan website layout design. Kata kunci : website design layout, sikap, niat membeli kembali
\end{abstract}

\begin{abstract}
The purpose of this research is to know the relation between website layout design, attitude and repurchase intention. The research is targeting the customer of lazada.co.id who domiciled in Bali. Sample's size of the research is 90 respondents with non-probability sampling method Process of collecting the respondent's data is by distributing questionnaire. $P$ artial Least Square and Sobel test are used or the instrument's research. Result of analysis shown that direct relation between website layout design, attitude and repurchase intention have significant positive relation. While, the indirect relation, attitude able to be mediation variable that associated two variables, such as website layout design and repurchase intention. It describes repurchase intention will increase if positive attitude of lazada.co.id customer also increase as the impact of well display of website layout design.

Keywords: website layout design, attitude, repurchase intention
\end{abstract}




\section{PENDAHULUAN}

Asosiasi Penyelenggara Internet Indonesia (APJII) mengadakan survey bersama teknopreneur.com tentang perilaku pengguna internet di Indonesia pada tahun 2017. Survey tersebut diikuti oleh 2500 responden yang tersebar di 6 wilayah Indonesia (Sumatera, Kalimantan, Jawa, Sulawesi, Bali Nusa, Maluku Papua). Dalam 20 tahun terakhir, Indonesia selalu mengalami pertumbuhan pengguna Internet tiap tahunnya. Hingga saat ini, pengguna Internet Indonesia sudah melebihi $50 \%$ dari total penduduk Indonesia, tepatnya $54,68 \%$ yaitu 143,26 juta jiwa (Anggraeny et al., 2018).

Meningkatnya pengguna internet juga mempertegas bahwa internet sudah menjadi bagian dalam kehidupan masyarakat dunia yang tak dapat dipisahkan (Megantara \& Suryani, 2016). Dengan adanya perilaku masyarakat Indonesia yang cenderung melakukan kegiatan dengan menggunakan handphone dan internet, membuat para pelaku bisnis mulai melakukan usaha berbasis toko online atau bisa disebut juga desngan istilah e-commerce. APJII dalam survei yang sama juga menjelaskan bahwa perilaku pengguna internet Indonesia didominasi oleh kegiatan jual - beli barang secara online, yaitu $49.02 \%$. Hal tersebut menjelaskan bahwa $e$ commerce memang sedang berkembang dengan pesat di Indonesia (Hernandhi et al., 2018).

Provinsi Bali merupakan salah satu daerah Indonesia dengan jumlah pengguna internet yang cukup tinggi yang berkembang cukup pesat. Pada tahun 2014 APJII menyatakan bahwa penetrasi pengguna internet di Bali hampir mencapai setengah jumlah populasi, tepatnya, 49\%. Kemudian, berdasarkan data APJII pada tahun 2017 penetrasi pengguna internet di Bali dan Nusa Tenggara sebanyak 54,23\%.(Dwipayana \& Sulistyawati, 2018)

Hal terpenting dalam e-commerce adalah website (Kashif et al., 2017). Pertumbuhan jumlah website di dunia berdasarkan internetlivestats.com pada tahun 2013 telah tumbuh dari sekitar 630 juta website di awal tahun hingga lebih dari 850 juta pada Desember 2013. Pertumbuhan terbesar adalah tahun 2016, berawal dari bulan Januari sampai Desember. Pertumbuhannya dimulai dari 900 juta website dan hampir menjadi dua kali lipat, yaitu 1,7 miliar website. Hal ini menunjukan bahwa pertumbuhan website mengalami peningkatan tiap tahunnya. Lazada berada pada posisi pertama dalam peringkat kinerja online consumer goods retailers di Indonesia. Total populasi digital mencapai 21.235.000, Lazada mengalahkan Blibli.com yang berada di peringkat kedua dengan populasi 15.556 .000 . Kemudian disusul oleh tokopedia pada peringkat ketiga dengan populasi 14.401.000 (Nazirah \& Sorayanti, 2017).

Pada tahun 2016 Alibaba Group Holding resmi mengakusisi Lazada dengan suntikan dana sebesar 1 miliar dolar AS atau setara Rp 13,7 triliun. Sebagai raksasa e-commerce di China. Melihat perkembangan yang mulai signifikan pada 2017, Alibaba meningkatkan sahamnya di Lazada hingga 83 persen mealalui tambahan investasi terbaru pada Maret 2018 lalu, tercatat Alibaba sudah memberikan investasi sekitar 4 miliar dollar AS atau sekitar Rp 55 triliun kepada Lazada (Alam \& Adam, 2017).

Total transaksi atau Gross Merchandize Value (GMV) tahunan Lazada pada tahun 2013 memperoleh jumlah transaksi Rp 1,2 triliun. Pada tahun 2014 total 
transaksi Lazada mengalami peningkatan menjadi lebih dari Rp 4 triliun. Indonesia merupakan pasar pasar terbesar Lazada di Asia Tenggara, bahkan disebutkan bahwa Indonesia merupakan pasar utama dengan 30\% total transaksi di Lazada pada tahun 2014 berasal dari pembeli Indonesia. Dalam Situs money.id (2016) menyatakan bahwa hingga Maret 2016 Lazada berhasil mencetak GMV tahunan senilai lebih dari Rp 17 triliun. Berdasarkan data diatas Lazada memang sedang mengalami peningkatan yang pesat dalam total populasi digital dan total GMV. Hal ini menjelaskan bahwa Lazada merupakan website e-commerce terpopuler Indonesia (Sari et al., 2017).

Lazada Indonesia sebagai pendiri situs Lazada.co.id didirikan pada tahun 2012 dan merupakan bagian dari Lazada Group yang beroperasi di Asia Tenggara. Lazada.co.id adalah perintis e-commerce (online shopping) di beberapa negara dengan pertumbuhan tercepat di dunia yang menawarkan pengalaman belanja online cepat, aman dan nyaman. Lazada Indonesia menawarkan solusi untuk masyarakat Indonesia agar dapat menikmati berbagai kemudahan dalam berbelanja online, salah satunya menyediakan website yang mudah digunakan. Lazada menjamin kenyamanan konsumennya ketika browsing produk yang sedang dicari (Adinata \& Yasa, 2018)

Dalam penelitian Chiu et al. (2014) dinyatakan bahwa rata-rata pelanggan harus berbelanja empat kali di toko online sebelum mendapat keuntungan dari pelanggan tersebut. Dalam penelitian yang sama niat beli kembali dinilai berperan sangat penting untuk meningkatkan keuntungan pada toko online. Niat beli kembali merupakan cerminan bahwa jasa yang ditawarkan perusahaan berkualitas sehingga pelanggan merasa puas (Putra \& Sulistyawati, 2018).

Kegiatan pembelian sering dilakukan oleh konsumen karena adanya niat untuk membeli produk yang sudah pernah di konsumsi dikarenakan konsumen sudah merasakan layanan yang dihasilkan oleh penjual (Lloyd \& Goode, 2014). Kontribusi lebih terhadap seperti ini dibutuhkan karena terbatasnya penenelitian mengenai niat membeli kembali terkait hubungannya dengan atmosphere website (Zhang et al., 2014)

Jika pemilik e-commerce ingin memiliki kemampuan bersaing yang baik, website yang dimilikinya harus didukung dengan layout desain yang menarik. Layout desain diartikan sebagai penataan konten dari informasi produk dan gambar yang ada di dalam website tersebut (Hasan \& Abuelrub, 2014). Dalam rangka memenuhi kebutuhan pengguna, desain website harus memenuhi prinsip- prinsip perancangan layout dalam membangun tampilan (Madhavaiah, 2015). Pengguna internet mengharapkan bahwa dalam merancang desain tata letak pada website perlu memperhatikan bagaimana posisi tata letak agar tidak menganggu kegiatan pengguna internet (Bitner, 2015). Tampilan layout website yang baik akan memberikan rasa nyaman untuk konsumen yang berkunjung (Sandy \& Dhillon, 2017), artinya sikap konsumen terpengaruhi oleh tampilan layout desain website.

Sikap dapat menyebabkan seseorang menilai suka atau tidak suka terhadap suatu objek yang dinilai yang diakibatkan evaluasi secara menyeluruh oleh penilai tersebut (Sany et al., 2014). Hal yang pertama kali dilihat konsumen saat berkunjung di toko online menentukan kesan penjual seperti apa yang terbangun di mata pembeli. Pelaku bisnis online tentu ingin sikap positif yang dirasakan oleh 
konsumennya, sehingga akan mempengaruhi kegiatan membeli dari konsumen (Hong et al., 2014). Pemasar dan pembuat keputusan dari situs web harus memperhatikan situs webnya karena ini adalah syarat penting yang mempengaruhi sikap konsumen yang pada akhirnya berujung pada kegiatan pembelian oleh konsumen (Thomas et al., 2018)

Berdasarkan latar belakang masalah yang telah diuraikan diatas, maka rumusan masalah bisa dirumuskan sebagai berikut: 1) Bagaimana pengaruh website layout design terhadap niat beli kembali konsumen Lazada.co.id? 2) Bagaimana pengaruh website layout design terhadap sikap konsumen Lazada.co.id ? 3) Bagaimana pengaruh sikap terhadap niat beli kembali konsumen Lazada.co.id ? 4) Bagaimana peran sikap dalam memediasi website layout design terhadap niat beli kembali konsumen Lazada.co.id?

Berdasarkan rumusan masalah yang sudah diuraikan diatas, maka yang menjadi tujuan dari penelitian ini adalah: 1) Menjelaskan pengaruh website layout design terhadap niat beli kembali konsumen Lazada.co.id 2) Menjelaskan pengaruh website layout design terhadap sikap konsumen Lazada.co.id 3) Menjelaskan pengaruh sikap terhadap niat beli kembali suatu produk di Lazada.co.id 4) Menjelaskan peran sikap dalam memediasi website layout design terhadap niat beli yang dimediasi oleh sikap konsumen Lazada.co.id

Penelitian ini diharapkan dapat mnjelaskan hubungan antar variabel website layout design, sikap dan niat membeli kembali konsumen sehingga akan menambah keragaman ilmu manajemen khususnya dalam bidang pemasaran serta memberikan informasi pada perancang website di lazada.co.id, sehingga membantu mereka dalam pengambilan keputusan secara khsusus untuk pengaturan layout design sebuah website.

Website adalah kumpulan file - file komputer yang disatukan menjadi informasi dan dapat diakses di internet menggunakan metode penentuan alamat yang unik. Berdasarkan fungsinya website dibagi menjadi 4 macam, yaitu personal website, government website, Non-profit organization website dan commercial website (E-commerce). Website yang dikategorikan sebagai e-commerce adalah seluruh website yang memiliki proses bisnis didalamnya. Dalam perkembangannya, e-commerce dan e-business sering digunakan secara bergantian sehingga istilah ini dianggap memiliki arti yang sama (Hernandhi et al., 2018).

Atmosfer website e-commerce terdiri dari 4 komponen, yaitu informativeness, website navigation, entertainment dan website. Layout atau tata letak adalah elemen desain komunikasi visual dasar yang harus ada dalam sebuah desain. Layout berfungsi mengatur elemen-elemen dalam sebuah karya agar menjadi suatu desain yang baik sehingga pesan dapat diterima dengan baik. Dalam dunia non-digital, layout yaitu merancang tata letak toko agar terlihat baik dan nantinya akan mampu mengundang konsumen untuk betah berkeliling lebih lama lagi dan membelanjakan uangnya lebih banyak (Kashif et al., 2017).

Definisi sikap adalah kecenderungan untuk menerima atau menolak sesuatu berdasarkan hasil evaluasi terhadap suatu objek atau produk secara positif atau negatif. Sikap merupakan faktor penting untuk menentukan bagaimana perilaku seseorang terhadap sesuatu. Sikap seorang terhadap suatu objek ditentukan oleh keyakinan dan hasil evaluasinya terhadap objek tersebut (Adinata \& Yasa, 2018). 
Sehingga, hubungan sikap terhadap website dalam penelitian ini dapat didefinisikan sebagai bentuk evaluasi emosional yang terjadi setelah melakukan kegiatan di sebuah situs web. Dalam pengukuran sikap terhadap website dapat menggunakan beberapa pengukuran yaitu 1) desain website ini nyaman buat saya; 2) suka meluangkan waktu untuk browsing situs semacam ini; 3) pembelian di situs semacam ini menyenangkan.

Definisi dari niat beli kembali adalah pendapat individu untuk membeli produk ataupun layanan pada perusahaan yang sama dengan mempertimbangkan situasi saat miliknya saat ini ini. Niat beli kembali dinilai berperan sangat penting untuk menghasilkan keuntungan yang didapat oleh suatu toko online. Dalam mengukur niat beli kembali dapat juga menggunakan pengukuran sebagai berikut (Idris, 2017): 1) Kecendrungan untuk membeli merek yang sama lagi; 2) Tidak akan mempertimbangkan merk lain; 3) Merek Tersebut selalu menjadi pilihan pertama; 4) Kesediaan membeli produk $X$ sangat tinggi; 5) Memperkirakan untuk melakukan pembelian ulang dalam waktu dekat.

Penelitian Kashif et al. (2017) menyatakan bahwa penelitian terdahulu mengenai hubungan antara website layout design dan niat beli kembali sangat terbatas karena keunikan dimensi dalam variabel website. Dalam penelitiannya disimpulkan bahwa terdapat hubungan positif signifikan antara layout website dan niat beli kembali secara online.

$\mathrm{H}_{1}$ :Website layout design berpengaruh positif signifikan terhadap niat beli kembali.

Penelitian Manganari et al. (2014) menemukan bahwa Kemudahan penggunaan tata letak virtual yang dirasakan secara positif signifikan mempengaruhi sikap konsumen terhadap toko online. Desain situs web berhubungan positif signifikan dengan keadaan kognitif konsumen (Yoon, 2014). Hipotesis oleh Lee et al. (2014) juga mendukung bahwa desain tata letak sebuah website memiliki pengaruh yang besar terhadap sikap konsumen online. Hal yang selaras juga mengungkapkan bahwa desain situs web di situs merek mewah akan memberi dampak positif signifikan pada sikap terhadap merek (H. Lee et al., 2015) $\mathrm{H}_{2}$ :Website layout design berpengaruh positif signifikan terhadap sikap.

Menurut Dewi \& Ardani (2016) meningkatnya sikap yang positif signifikan maka akan meningkatkan pula niat beli ulang konsumen, dinyatakan bahwa variabel sikap berpengaruh secara signifikan terhadap niat beli ulang konsumen. Pada penelitian sebelumnya yang dilakukan oleh Mao \& Lyu (2017) sikap memiliki pengaruh positif signifikan pada niat pelanggan untuk membeli kembali melalui situs Airbnb. Hasil penelitian lain juga menyatakan bahwa semakin tinggi sikap terhadap merek, semakin tinggi pula minat beli ulang konsumen (Hanfan, 2017).

$\mathrm{H}_{3}$ : Sikap berpengaruh positif signifikan terhadap niat beli kembali.

Hipotesis empat merupakan hasil modifikasi dari beberapa jurnal. Hubungan antara website layout design dan sikap memiliki hubungan yang positif signifikan (Manganari et al., 2014; Yoon, 2014; H. Lee et al., 2015). Hubungan positif signifikan juga terjadi antara sikap dan niat beli kembali (Dewi \& Ardani, 2016; Mao \& Lyu, 2017; Hanfan, 2017). Berdasarkan variabel sikap yang berperan sebagai variabel yang dipengaruhi oleh website layout design dan mempengaruhi variabel niat beli kembali, maka dalam penelitian ini variabel sikap diduga berperan sebagai variabel yang memediasi website layout design dan niat beli kembali. 
$\mathrm{H}_{4}$ :Sikap berpengaruh signifikan dalam memediasi website layout design terhadap niat beli kembali.

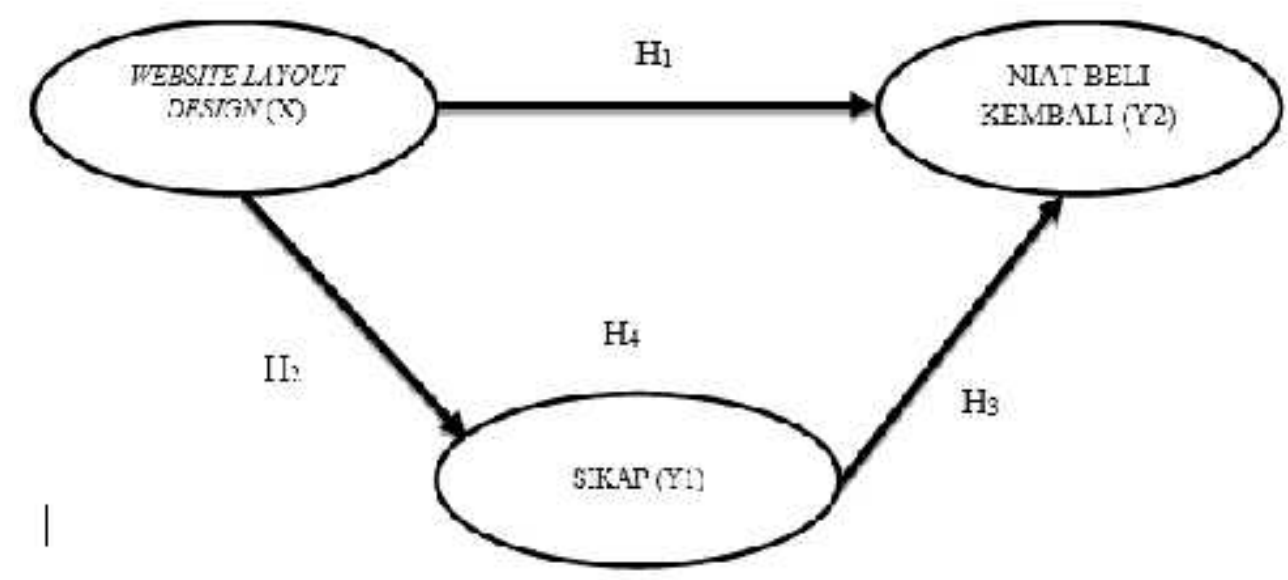

Gambar 1. Kerangka Konseptual

\section{METODE PENELITIAN}

Penelitian ini menggunakan pendekatan kuantitatif dengan bentuk asosiatif, yaitu penelitian yang bertujuan untuk mengetahui hubungan dari dua variabel atau lebih (Sugiyono, 2017:37). Metode ini digunakan untuk menyatakan hubungan antar variabel niat beli kembali, sikap, dan website layout design. Lokasi atau ruang lingkup penelitian ini bertempat di provinsi Bali. Dasar dari pemilihan lokasi adalah provinsi yang menempati posisi ketiga sebagai pengguna internet terbanyak di Indonesia.

Objek dalam penelitian ini adalah dalam bidang manajemen pemasaran yang berkaitan dengan perilaku konsumen, yaitu mengenai peran sikap dalam memediasi pengaruh website layout design terhadap niat beli kembali. Subjek dari penelitian ini adalah konsumen yang pernah membeli produk Lazada di Bali. Berdasarkan pada pokok masalah yang telah dirumuskan serta hipotesis yang diajukan, maka variabel-variabel dalam penelitian ini digolongkan menjadi dua jenis variabel yaitu variabel eksogen dan endogen. Variabel eksogen adalah variabel yang dianggap memiliki pengaruh terhadap variabel yang lain, namun tidak dipengaruhi oleh variabel lain dalam model. Variabel eksogen dalam penelitian ini yaitu website layout design $\left(\mathrm{X}_{1}\right)$. Variabel endogen adalah variabel yang dianggap dipengaruhi oleh variabel lain dalam model. Variabel endogen dalam penelitian ini yaitu sikap $\left(\mathrm{Y}_{1}\right)$ dan niat beli kembali $\left(\mathrm{Y}_{2}\right)$.

Populasi dalam penelitian ini yaitu seluruh penduduk Bali yang membeli produk di Lazada.co.id. Jumlah populasi tidak dapat dihitung (infinite). Penentuan sampel dalam penelitian ini diperlukan beberapa kriteria, yaitu yang pertama adalah responden sudah menyelesaikan pendidikan tingkat SMA atau sederajat, dengan pertimbangan responden sudah mampu menafsirkan dengan tepat setiap isi dari kuesioner. Kriteria kedua adalah responden sudah pernah membeli produk di situs web Lazada.co.id dalam jangka waktu maksimal satu tahun yang lalu, dengan 
pertimbangan lazada.co.id tidak mengalami banyak perubahan dalam hal desain layout situs webnya.

Berkaitan dengan beberapa kriteria dalam penentuan sampel yang digunakan, maka metode penentuan sampel dipilih dengan teknik non-probability sampling, yaitu metode yang tidak memberikan peluang atau kesempatan yang sama bagi setiap anggota populasi untuk dipilih menjadi sampel (Sugiyono, 2017:84) dengan bentuk purposive sampling.

Menurut Roscoe dalam buku Metode Penelitian Kuantitatif, Kualitatif, dan R\&D (Sugiyono, 2017:90) ukuran sampel yang layak adalah 30 sampai 500 sampel. Cara menentukan ukuran sampel yang disarankan adalah minimal 10 kali dari jumlah variabel atau indikator yang diteliti. Dalam penelitian ini terdapat 3 indkator pada masing - masing variabel yang diteliti yaitu niat beli kembali, sikap, dan website layout design. Total indikator adalah 9, sehingga ukuran sampel dalam penelitian ini berjumlah 90 sampel ( 9 x 10).

Jenis data dalam penelitian ini ada dua yaitu data kualitatif dan kuantitatif. Data kuantitatif dalam penelitian ini adalah skor jawaban kuesioner peran sikap dalam memediasi website layout design dan niat beli kembali. Data kualitatif dalam penelitian ini adalah pendapat dari responden yang meliputi variabel website layout design, sikap, dan niat beli kembali. Terdapat dua sumber data yaitu primer dan sekunder. Data primer dalam penelitian ini adalah hasil jawaban kuesioner mengenai peran sikap dalam memediasi website layout design dan niat beli kembali. Data sekunder dalam penelitian ini adalah gambaran umum tentang variabel - variabel yang diteliti, yaitu website layout design, sikap dan niat beli kembali yang diperoleh dari internet dan buku.

Data dikumpulkan dengan menyebarkan kuesioner menggunakan Google form yang disebar secara online kepada konsumen lazada.co.id di Indonesia. Dengan pengukuran skala likert dengan skala 1 sampai 5. Uji validitas diperlukan untuk pengujian data yang didapat dari kuesioner sebagai instrumen. Uji tingkat validitas dinyatakan valid jika koefisien korelasi mendapatkan hasil $\geq 0,30$ (Sugiyono, 2017:134). Uji validitas ini bertujuan untuk memeriksa apakah isi kuisioner sudah tepat untuk mengukur apa yang ingin diukur dan cukup dipahami oleh semua responden, yang diindikasikan oleh kecilnya presentase jawaban reponden yang tidak terlalu menyimpang dari responden lainnya.

Uji reliabilitas bertujuan untuk mencari tahu sampai sejauh mana konsentrasi alat ukur yang digunakan, sehingga bila alat ukur tersebut digunakan kembali untuk meneliti obyek yang sama dan teknik yang sama dengan waktu yang berbeda maka hasil yang diperoleh akan sama. Uji reliabilitas mampu menunjukkan sejauh mana instrument dapat dipercaya dan diandalkan. Uji reliabilitas dalam penelitian ini menggunakan alpha crobnbach dinyatakan valid dan reliable jika sudah melebihi batas minimal sebesar $\geq 0,6$.

Teknik analisis data yang digunakan untuk penelitian ini adalah statistik deskriptif dan statistik inferensial. Statistik inferensial digunakan untuk membuat kesimpulan yang berlaku untuk populasi (Sugiyono, 2017:147). Bentuk statistik inferensial yang digunakan dalam penelitian ini adalah Partial Least Squares (PLS) dan Uji Sobel. PLS merupakan salah satu metode analisa yang bisa diterapkan untuk seluruh skala data, tidak memerlukan asumsi yang banyak, ukuran sampelnya 
tidak diharuskan besar, dapat dipergunakan untuk pembuktian teori, dan juga dapat digunakan untuk mengembangkan hubungan yang belum mempunyai landasan teori yang kuat. Hal ini selaras dengan hubungan antara variabel website layout design dan niat beli kembali yang masih membutuhkan banyak peneliti untuk melakukan penelitian yang menjelaskan hubungan kedua variabel tersebut.

Uji Sobel dilakukan untuk menguji signifikansi pengaruh tidak langsung variabel eksogen terhadap variabel tujuan (endogen) melalui variabel mediasi. Uji Sobel dihitung dengan menggunakan aplikasi Microsoft Excel 2016. Nilai koefisien z jika lebih besar dari 1,96, maka variabel mediasi dinilai secara signifikan mampu memediasi hubungan pengaruh vaiabel eksogen terhadap variabel endogen.

\section{HASIL DAN PEMBAHASAN}

Lazada diluncurkan pada bulan Maret 2012. Perkembangan pesat hingga saat ini, Lazada Indonesia merupakan salah satu bagian dari jaringan retail online Lazada Group yang beroperasi di enam negara di Asia Tenggara, yang terdiri dari Lazada Indonesia, Lazada Malaysia, Lazada Thailand, Lazada Vietnam, Lazada Singapore dan Lazada Filipina. Sebagai pelopor ekosistem e-commerce di Asia Tenggara, Lazada telah membantu lebih dari 135.000 penjual lokal dan internasional, serta 3.000 brand untuk melayani 560 juta konsumen di kawasan Asia Tenggara.

Lazada menawarkan variasi produk dalam berbagai kategori mulai dari barang elektronik hingga barang keperluan rumah tangga, mainan, fashion, perlengkapan olahraga dan kebutuhan sehari-hari. Sebagai bentuk komitmen Lazada untuk mengedepankan pengalaman berbelanja online yang menyenangkan bagi para konsumen. Lazada Indonesia juga menawarkan solusi untuk masyarakat Indonesia agar dapat menikmati kemudahan dalam berbelanja online, yaitu menyediakan website yang mudah digunakan. Lazada menjamin kenyamanan konsumennya ketika browsing produk yang sedang dicari.

Lazada Group sendiri merupakan salah satu anak perusahaan internet Jerman bernama Rocket Internet. Rocket Internet merupakan perusahaan inkubator online yang sukses menciptakan perusahaan-perusahaan online inovatif di berbagai belahan dunia. Berkantor pusat di Berlin, Jerman, proyek yang dimiliki Rocket Internet, antara lain Zalando, TopTarif, eDarling, Groupon (sebelumnya CityDeal).

Pada tahun 2016 Alibaba Group Holding resmi mengakusisi Lazada dengan suntikan dana sebesar 1 miliar dolar AS atau setara Rp 13,7 triliun. Sebagai raksasa e-commerce di China, tentu saja Alibaba bisa mendapatkan konsumen yang lebih luas lagi. Melihat perkembangan yang mulai signifikan pada 2017, Alibaba meningkatkan sahamnya di Lazada hingga 83 persen mealalui tambahan investasi terbaru pada Maret 2018 lalu, tercatat Alibaba sudah memberikan investasi sekitar 4 miliar dollar AS atau sekitar Rp 55 triliun kepada Lazada. Salah satu dari 18 pendiri Alibaba yakni Lucy Peng menggantikan peranan Max Bittner sebagai CEO Lazada Group. Sebelumnya, Lucy Peng masih menjabat sebagai CEO di perusahaan afiliasi Alibaba, Ant Financial. Sedangkan, kedudukan orang paling tinggi di Lazada Indonesia diduduki oleh Alessandro Piscini sejak Mei 2018.

Karakteristik responden penelitian merupakan profil dari 90 responden yang telah berpartisipasi dalam pengisian kuesioner penelitian ini. Profil responden 
memaparkan Umur dan pekerjaan. Karakteristik responden, berdasarkan kriteria umur dominasi responden diikuti oleh responden yang memiliki rentang umur 1923 tahun, yaitu sebesar 83,3 persen. Sedangkan persentase terendah dimiliki oleh responden dengan umur lebih dari 33 tahun dengan presentase 2,2 persen. Karakteristik responden, berdasarkan kriteria pekerjaan responden, didominasi oleh responden dengan pekerjaan Mahasiswa dengan persentase sebesar 68,9 persen. Hal ini menggambarkan bahwa konsumen e-commerce didominasi oleh masyarakat yang berusia muda.

\section{Tabel 1.}

\section{Hasil Uji Validitas Instrumen Penelitian}

\begin{tabular}{|c|c|c|c|}
\hline Variabel & & Indikator & Pearson Correlation \\
\hline \multirow[t]{3}{*}{$\begin{array}{l}\text { Website design } \\
\text { layout }\end{array}$} & $\mathrm{X}_{1.1}$ & $\begin{array}{l}\text { Website Lazada.co.id tertata dengan } \\
\text { rapi. }\end{array}$ & 0,851 \\
\hline & $\mathrm{X}_{1.2}$ & $\begin{array}{l}\text { Website Lazada.co.id menyediakan } \\
\text { simbol navigasi yang membantu } \\
\text { (contoh:menu). }\end{array}$ & 0,809 \\
\hline & $\mathrm{X}_{1.3}$ & Website Lazada.co.id user-friendly. & 0,848 \\
\hline \multirow[t]{3}{*}{ Sikap } & $\mathrm{Y}_{1.1}$ & $\begin{array}{l}\text { Lazada.co.id adalah website yang } \\
\text { bagus. }\end{array}$ & 0,850 \\
\hline & $\mathrm{Y}_{1.2}$ & $\begin{array}{l}\text { Lazada.co.id adalah website yang } \\
\text { menyenangkan. }\end{array}$ & 0,853 \\
\hline & $\mathrm{Y}_{1.3}$ & $\begin{array}{l}\text { Lazada.co.id adalah website yang } \\
\text { nyaman untuk saya. }\end{array}$ & 0,826 \\
\hline \multirow[t]{3}{*}{$\begin{array}{l}\text { Niat Beli } \\
\text { Kembali }\end{array}$} & $\mathrm{Y}_{2.1}$ & $\begin{array}{l}\text { Jika ada kesempatan, saya akan } \\
\text { melanjutkan untuk membeli produk } \\
\text { pada Lazada.co.id di masa yang akan } \\
\text { datang. }\end{array}$ & 0,763 \\
\hline & $\mathrm{Y}_{2.2}$ & $\begin{array}{l}\text { Lazada.co.id adalah pilihan utama } \\
\text { saya dalam berbelanja online. } \\
\text { Sepertinya saya akan tetap membeli } \\
\text { produk dari Lazada.co.id di masa }\end{array}$ & 0,910 \\
\hline & $\mathrm{Y}_{2.3}$ & yang akan datang. & 0,900 \\
\hline
\end{tabular}
Sumber: Data diolah, 2019.

Tabel 1. menunjukkan bahwa seluruh instrumen dalam penelitian memiliki angka Pearson Correlation yang lebih besar dari angka 0,30. Berdasarkan hasil tersebut dapat disimpulkan bahwa seluruh instrumen variabel dalam penelitian ini adalah valid sehingga dapat digunakan sebagai instrumen penelitian. Berdasarkan

Tabel 2. nilai seluruh Cronbach's Alpha menunjukkan nilai lebih dari 0,6. Dari hasil tersebut menunjukkan bahwa semua instrumen reliabel atau kehandalan dalam mengukur variabel dalam penelitian ini, sehingga variabel-variabel tersebut dapat digunakan untuk melakukan penelitian.

Pengumpulan data dilakukan dengan penyebaran kuesioner secara tidak langsung melalui Google Form kepada responden untuk dijawab sendiri. Kuesioner yang disebarkan memuat pernyataan-pernyataan yang berhubungan dengan variabel yang diteliti, yaitu website layout design, sikap, dan niat beli kembali untuk mengetahui penilaian pelanggan mengenai variabel-variabel tersebut. Dalam 
rangka mendeskripsikan penilaian responden mengenai variabel-variabel dalam penelitian perlu dilakukan penggolongan jawaban responden ke dalam 5 skala pengukuran.

Tabel 2.

Hasil Uji Reliabilitas Instrumen Penelitian

\begin{tabular}{ccc}
\hline Variabel & Cronbach'sAlpha & Keterangan \\
\hline Website Layout Design & 0,785 & Reliabel \\
Sikap & 0,794 & Reliabel \\
Niat Beli Kembali & 0,820 & Reliabel \\
\hline
\end{tabular}

Sumber: Data diolah, 2019.

Variabel website layout design dalam penelitian ini merupakan satu - satunya variabel bebas $\left(\mathrm{X}_{1}\right)$, total pernyataan yang diukur dalam variabel ini yaitu sebanyak tiga pernyataan, secara rinci hasil penelitian mengenai penilaian responden terhadap website layout design disajikan pada Tabel 3.

Tabel 3.

Deskripsi Penilaian Responden Terhadap Variabel Website Design Layout

\begin{tabular}{|c|c|c|c|c|c|c|c|c|}
\hline & \multirow[b]{2}{*}{ Indikator } & \multicolumn{5}{|c|}{ Skor Jawaban } & \multirow[b]{2}{*}{$\begin{array}{l}\text { Rata- } \\
\text { rata }\end{array}$} & \multirow[b]{2}{*}{ Keterangan } \\
\hline & & $\begin{array}{l}\text { STS } \\
(1)\end{array}$ & $\begin{array}{l}\text { TS } \\
(2)\end{array}$ & $\begin{array}{l}\mathbf{N} \\
(3)\end{array}$ & $\begin{array}{c}S \\
(4)\end{array}$ & $\begin{array}{l}\text { SS } \\
(5)\end{array}$ & & \\
\hline $\mathrm{X}_{1.1}$ & $\begin{array}{l}\text { Website Lazada.co.id tertata } \\
\text { dengan rapi. }\end{array}$ & 0 & 1 & 22 & 54 & 13 & 3,88 & Baik \\
\hline $\mathrm{X}_{1.2}$ & $\begin{array}{l}\text { Website Lazada.co.id } \\
\text { menyediakan simbol } \\
\text { navigasi yang membantu } \\
\text { (contoh:menu). }\end{array}$ & 0 & 1 & 15 & 57 & 17 & 4,00 & Baik \\
\hline $\mathrm{X}_{1.3}$ & $\begin{array}{l}\text { Website Lazada.co.id user- } \\
\text { friendly. }\end{array}$ & 0 & 0 & 31 & 44 & 15 & 3,82 & Baik \\
\hline \multicolumn{7}{|c|}{ Rata-rata skor website design layout } & 3,90 & Baik \\
\hline
\end{tabular}
Sumber: Data diolah, 2019.

Berdasarkan Tabel 3. pernyataan yang memiliki nilai rata-rata tertinggi adalah pernyataan $\mathrm{X}_{1.2}$ yaitu yang menyatakan bahwa Website Lazada.co.id menyediakan simbol navigasi yang membantu (contoh:menu), pernyataan ini masuk dalam kategori baik karena berada di rentang interval 3,41-4,20.

Secara keseluruhan variabel website layout design masuk dalam kategori baik, hal ini dapat dilihat dengan menjumlahkan rata-rata setiap pernyataan kemudian dibagi dengan jumlah pernyataan dan memperoleh rata-rata skor website layout design sebesar 3,90. Hasil rata-rata skor website layout design masuk dalam kategori tinggi karena berada di rentang interval 3,41-4,20. Hal ini berarti bagi responden website design layout Lazada.co.id memiliki tampilan yang sangat baik karena rata-rata skor variabel website layout design masuk dalam kategori tinggi.

Variabel sikap dalam penelitian ini merupakan variabel terikat pertama ( $\left.\mathrm{Y}_{1}\right)$, total pernyataan yang diukur dalam variabel ini yaitu sebanyak tiga pernyataan, secara rinci hasil penelitian mengenai penilaian responden terhadap variabel sikap disajikan pada Tabel 4 . 
Berdasarkan Tabel 4. pernyataan yang memiliki nilai rata-rata tertinggi adalah pernyataan $\mathrm{Y}_{1.1}$ yaitu yang menyatakan bahwa Lazada.co.id adalah website yang bagus, pernyataan ini masuk dalam kategori positif karena berada di rentang interval 3,41 - 4,20. Rata-rata terendah terdapat pada pernyataan $\mathrm{Y}_{1.2}$ yaitu yang menyatakan bahwa Lazada.co.id adalah website yang menyenangkan. Walaupun pernyataan $\mathrm{Y}_{1.2}$ berada pada posisi rata -rata terendah, pernyataan ini tetap dikategorikan tinggi karena berada pada interval 3,41 - 4,20.

Tabel 4.

Deskripsi Penilaian Responden Terhadap Variabel Sikap

\begin{tabular}{|c|c|c|c|c|c|c|c|c|}
\hline \multirow{2}{*}{\multicolumn{2}{|c|}{ Indikator }} & \multicolumn{5}{|c|}{ Skor Jawaban } & \multirow[b]{2}{*}{$\begin{array}{l}\text { Rata- } \\
\text { rata }\end{array}$} & \multirow[b]{2}{*}{ Keterangan } \\
\hline & & $\begin{array}{c}\text { STS } \\
(1)\end{array}$ & $\begin{array}{l}\text { TS } \\
(2)\end{array}$ & $\begin{array}{l}\mathbf{N} \\
(3)\end{array}$ & $\begin{array}{l}\text { S } \\
(4)\end{array}$ & $\begin{array}{l}\text { SS } \\
(5)\end{array}$ & & \\
\hline $\mathrm{Y}_{1.1}$ & $\begin{array}{l}\text { Lazada.co.id adalah } \\
\text { website yang bagus. } \\
\text { Lazada.co.id adalah }\end{array}$ & 0 & 0 & 24 & 49 & 17 & 3,92 & Positif \\
\hline $\mathrm{Y}_{1.2}$ & $\begin{array}{l}\text { website yang } \\
\text { menyenangkan. }\end{array}$ & 0 & 1 & 25 & 50 & 14 & 3,86 & Positif \\
\hline $\mathrm{Y}_{1.3}$ & $\begin{array}{l}\text { Lazada.co.id adalah } \\
\text { website yang nyaman } \\
\text { untuk saya. }\end{array}$ & 1 & 2 & 17 & 55 & 15 & 3,90 & Positif \\
\hline \multicolumn{7}{|c|}{ Rata-rata skor sikap } & 3,89 & Positif \\
\hline
\end{tabular}

Sumber: Data diolah, 2019.

Secara keseluruhan variabel sikap masuk dalam kategori positif, hal ini dapat dilihat dengan menjumlahkan rata-rata setiap pernyataan kemudian dibagi dengan jumlah pernyataan dan memperoleh rata-rata skor sikap sebesar 3,89. Hasil ratarata skor sikap masuk dalam kategori positif karena berada di rentang interval 3,41 - 4,20. Hal ini berarti sikap responden terhadap website Lazada.co.id memiliki sikap yang positif karena rata-rata skor variabel sikap masuk dalam kategori positif.

Variabel niat membeli kembali dalam penelitian ini merupakan variabel terikat kedua $\left(\mathrm{Y}_{2}\right)$, total pernyataan yang diukur dalam variabel ini yaitu sebanyak tiga pernyataan, secara rinci hasil penelitian mengenai penilaian responden terhadap variabel niat membeli kembai disajikan pada Tabel 5 sebagai berikut:

Berdasarkan Tabel 5. pernyataan yang memiliki nilai rata-rata tertinggi adalah pernyataan $Y_{2.1}$ yaitu yang menyatakan bahwa Jika ada kesempatan, saya akan melanjutkan untuk membeli produk pada Lazada.co.id di masa yang akan datang. Pernyataan ini masuk dalam kategori tinggi karena berada di rentang interval 3,41-4,20. Rata-rata terendah terdapat pada pernyataan $\mathrm{Y}_{2.2}$ yaitu yang menyatakan bahwa Lazada.co.id adalah pilihan utama saya dalam berbelanja online. Walaupun pernyataan $\mathrm{Y}_{2.2}$ berada pada posisi rata-rata terendah, pernyataan ini tetap dikategorikan tinggi karena berada pada interval 3,41-4,20.

Secara keseluruhan variabel niat membeli kembali masuk dalam kategori tinggi, hal ini dapat dilihat dengan menjumlahkan rata-rata setiap pernyataan kemudian dibagi dengan jumlah pernyataan dan memperoleh rata-rata skor sikap sebesar 3,67. Hasil rata-rata skor sikap masuk dalam kategori tinggi karena berada di rentang interval 3,41-4,20. . Hal ini berarti tingkat niat responden untuk membeli kembali ptroduk di Lazada.co.id tinggi. 
Tabel 5.

Deskripsi Penilaian Responden Terhadap Variabel Niat Membeli Kembali

\begin{tabular}{|c|c|c|c|c|c|c|c|c|}
\hline & \multirow[b]{2}{*}{ Indikator } & \multicolumn{5}{|c|}{ Skor Jawaban } & \multirow[b]{2}{*}{$\begin{array}{l}\text { Rata- } \\
\text { rata }\end{array}$} & \multirow[b]{2}{*}{ Keterangan } \\
\hline & & $\begin{array}{c}\text { STS } \\
\text { (1) }\end{array}$ & $\begin{array}{l}\text { TS } \\
\text { (2) }\end{array}$ & $\begin{array}{c}\mathbf{N} \\
\text { (3) }\end{array}$ & $\begin{array}{c}\text { S } \\
(4)\end{array}$ & $\begin{array}{l}\text { SS } \\
\text { (5) }\end{array}$ & & \\
\hline $\mathrm{Y}_{2.1}$ & $\begin{array}{l}\text { Jika ada kesempatan, saya } \\
\text { akan melanjutkan untuk } \\
\text { membeli produk pada } \\
\text { Lazada.co.id di masa yang } \\
\text { akan datang. }\end{array}$ & 1 & 0 & 18 & 55 & 16 & 3,94 & Tinggi \\
\hline $\mathrm{Y}_{2.2}$ & $\begin{array}{l}\text { Lazada.co.id adalah pilihan } \\
\text { utama saya dalam } \\
\text { berbelanja online. }\end{array}$ & 3 & 6 & 42 & 27 & 12 & 3,43 & Tinggi \\
\hline $\mathrm{Y}_{2.3}$ & $\begin{array}{l}\text { Sepertinya saya akan tetap } \\
\text { membeli produk dari } \\
\text { Lazada.co.id di masa yang } \\
\text { akan datang. }\end{array}$ & boli & mhali & 31 & 45 & 9 & 3,63 & Tinggi \\
\hline
\end{tabular}

Sumber: Data diolah, 2019.

Validitas model dibahas terlebih dahulu, sebelum membahas signifikansi pengaruh langsung masing-masing variabel eksogen terhadap variabel endogen dalam model penelitian. Terdapat tiga kriteria didalam penggunaan teknik analisis data dengan Smart PLS untuk menilai outer model yaitu convergent validity, discriminant validity, serta average variance extracted (AVE). Outer model dinilai dengan cara melihat convergent validity (besarnya factor loading untuk masingmasing konstruk). Penelitian ini menggunakan batas minimal loading factor sebesar 0,5.

Tabel 6.

Outer Loadings

\begin{tabular}{lcc}
\hline \multicolumn{1}{c}{ Variabel } & Indikator & Factor Loading \\
\hline \multirow{3}{*}{ Website Layout Design } & $\mathrm{X}_{1.1}$ & 0,873 \\
& $\mathrm{X}_{1.2}$ & 0,808 \\
& $\mathrm{X}_{1.3}$ & 0,826 \\
Sikap & $\mathrm{Y}_{1.1}$ & 0,872 \\
& $\mathrm{Y}_{1.2}$ & 0,846 \\
& $\mathrm{Y}_{1.3}$ & 0,809 \\
Niat Membeli Kembali & $\mathrm{Y}_{2.1}$ & 0,779 \\
& $\mathrm{Y}_{2.2}$ & 0,893 \\
& $\mathrm{Y}_{2.3}$ & 0,904
\end{tabular}

Sumber: Data diolah, 2019.

Hasil pengolahan pada Tabel 6. memperlihatkan bahwa nilai outer model telah memenuhi kriteria convergent validity, semua indikator memiliki factor loading di atas 0,50, sehingga dapat disimpulkan bahwa konstruk mempunyai convergent validity yang baik. 
Tabel 7.

Cross Loadings

\begin{tabular}{lccc}
\hline & Niat Membeli Kembali (Y2) & Sikap (Y1) & Website Layout Design $(\mathbf{X})$ \\
\hline $\mathrm{X}_{1.1}$ & 0.645 & 0.657 & $\mathbf{0 . 8 7 3}$ \\
$\mathrm{X}_{1.2}$ & 0.587 & 0.507 & $\mathbf{0 . 8 0 8}$ \\
$\mathrm{X}_{1.3}$ & 0.555 & 0.508 & $\mathbf{0 . 8 2 6}$ \\
$\mathrm{Y}_{1.1}$ & 0.631 & $\mathbf{0 . 8 7 2}$ & 0.648 \\
$\mathrm{Y}_{1.2}$ & 0.513 & $\mathbf{0 . 8 4 6}$ & 0.538 \\
$\mathrm{Y}_{1.3}$ & 0.616 & $\mathbf{0 . 8 0 9}$ & 0.504 \\
$\mathrm{Y}_{2.1}$ & $\mathbf{0 . 7 7 9}$ & 0.559 & 0.579 \\
$\mathrm{Y}_{2.2}$ & $\mathbf{0 . 8 9 3}$ & 0.627 & 0.596 \\
$\mathrm{Y}_{2.3}$ & $\mathbf{0 . 9 0 4}$ & 0.617 & 0.665 \\
\hline
\end{tabular}

Sumber: Data diolah, 2019.

Data pada Tabel 7. menjelaskan bahwa nilai cross loading menunjukkan adanya discriminant validity yang baik. Hal tersebut dapat dilihat dari nilai korelasi indikator terhadap konstruknya (loading factor) lebih tinggi dibandingkan nilai korelasi indikator tersebut dengan konstruk lainnya. Menguji reliabilitas PLS dengan membandingkan nilai akar dari Average Variant Extracted (AVE) setiap konstruk dengan korelasi antara konstruk dengan konstruk lainnya.

Tabel 8.

Nilai AVE

\begin{tabular}{lcc}
\hline & AVE & Akar AVE \\
\hline Niat Membeli Kembali $\left(\mathrm{Y}_{2}\right)$ & 0.740 & 0.860 \\
Sikap $\left(\mathrm{Y}_{1}\right)$ & 0.711 & 0.843 \\
Website Layout Design $(\mathrm{X})$ & 0.699 & 0.836 \\
\hline
\end{tabular}

Sumber: Data diolah, 2019.

Akar AVE pada Tabel 8. akan dibandingkan dengan nilai korelasi antar variabel bebas seperti ditunjukkan pada Tabel 9. berikut:

Tabel 9.

Korelasi antar variabel Laten

\begin{tabular}{|c|c|c|c|}
\hline & $\begin{array}{l}\text { Niat Membeli Kembali } \\
\text { (Y2) }\end{array}$ & $\begin{array}{l}\text { Sikap } \\
\text { (Y1) }\end{array}$ & $\begin{array}{l}\text { Website Layout Design } \\
\text { (X) }\end{array}$ \\
\hline $\begin{array}{l}\text { Niat Membeli Kembali } \\
\text { (Y2) }\end{array}$ & 1.000 & & \\
\hline Sikap (Y1) & 0.700 & 1.000 & \\
\hline $\begin{array}{l}\text { Website Layout Design } \\
\text { (X) }\end{array}$ & 0.714 & 0.673 & 1.000 \\
\hline
\end{tabular}

Sumber: Data diolah, 2019.

Tabel 8. menunjukkan bahwa akar AVE terendah adalah 0,836. Nilai korelasi antar konstruk terbesar pada Tabel 9 adalah 0,714. Dengan demikian semua nilai 
akar AVE lebih besar daripada nilai korelasi antar konstruk sehingga dapat dikatakan bahwa data sudah reliabel.

Tabel 10.

Nilai R-squares

\begin{tabular}{lc}
\hline & R Square \\
\hline Niat Membeli Kembali $\left(\mathrm{Y}_{2}\right)$ & 0.598 \\
Sikap $\left(\mathrm{Y}_{1}\right)$ & 0.453 \\
\hline
\end{tabular}

Sumber: Data diolah, 2019.

Data pada Tabel 10. menunjukkan bahwa nilai R-squares variabel niat membeli kembali $\left(\mathrm{Y}_{2}\right)$ pada tabel sebesar 0,598. Interpretasi dari hasil tersebut adalah bahwa 59,8 persen variabilitas konstruk niat membeli kembali dijelaskan oleh variabel website layout design $\left(\mathrm{X}_{1}\right)$, sedangkan 40,2 persen variabel niat beli kembali dijelaskan oleh variabel di luar model. Demikian pula nilai R-squares variabel sikap sebesar 0,453. Interpretasi dari hasil tersebut adalah bahwa 45,3 persen variabilitas konstruk sikap dijelaskan oleh variabel website layout design $\left(\mathrm{X}_{1}\right)$, sedangkan 54,7 persen variabel sikap dijelaskan oleh variabel di luar model.

Tabel 11.

Path Coefficient (Mean, STDEV, T-VALUES)

\begin{tabular}{|c|c|c|c|c|c|}
\hline & $\begin{array}{l}\text { Original } \\
\text { Sample } \\
\text { (O) }\end{array}$ & $\begin{array}{l}\text { Sample } \\
\text { Mean (M) }\end{array}$ & $\begin{array}{l}\text { Standard } \\
\text { Deviation } \\
\text { (STDEV) }\end{array}$ & $\begin{array}{l}\text { T Statistics } \\
\text { (|O/STDEV|) }\end{array}$ & $\begin{array}{l}\mathbf{P} \\
\text { Values }\end{array}$ \\
\hline $\begin{array}{l}\text { Sikap (Y1) -> Niat } \\
\text { Membeli Kembali (Y2) }\end{array}$ & 0.400 & 0.408 & 0.112 & 3.561 & 0.000 \\
\hline $\begin{array}{l}\text { Website Layout Design (X) } \\
->\text { Niat Membeli Kembali } \\
\text { (Y2) }\end{array}$ & 0.445 & 0.440 & 0.122 & 3.649 & 0.000 \\
\hline $\begin{array}{l}\text { Website Layout Design (X) } \\
->\text { Sikap (Y1) }\end{array}$ & 0.673 & 0.673 & 0.077 & 8.741 & 0.000 \\
\hline
\end{tabular}

Pengujian hipotesis pertama menunjukkan hasil bahwa hubungan antara website design layout dengan niat beli kembali adalah signifikan dengan t-statistik sebesar 3,649 ( >1,96 ). Nilai koefisien jalur sebesar 0,445 menunjukkan bahwa arah hubungan antara website design layout dengan niat membeli kembali adalah positif. Hipotesis $\mathrm{H}_{1}$ dalam penelitian ini menyatakan bahwa website design layout berpengaruh positif dan signifikan terhadap niat membeli kembali dapat diterima. Hasil ini menjelaskan bahwa semakin baik tampilan website layout design semakin meningkatkan niat membeli kembali konsumen lazada.co.id.

Hasil ini sejalan dengan penelitian terdahulu yang pernah dilakukan oleh Kashif et al. (2017). Dalam penelitiannya dinyatakan bahwa terdapat hubungan positif signifikan antara layout website dan niat beli kembali secara online. Dalam penelitiannya juga dinyatakan bahwa hubungan antara website layout design dan niat membeli kembali sangat terbatas karena keunikan dimensi dalam variabel website. Sehingga, hubungan yang dihasilkan dalam penelitian ini, yaitu antara 
website layout design dan niat membeli kembali akan membantu keterbatsan tentang penelitian yang menyatakan hubungan ini.

Pengujian hipotesis kedua menunjukkan hasil bahwa hubungan antara website layout design dengan sikap adalah signifikan dengan t-statistik sebesar 8,741 ( >1,96 ). Nilai koefisien jalur sebesar 0,673 menunjukkan bahwa arah hubungan antara website layout design dengan sikap adalah positif. Hipotesis $\mathrm{H}_{2}$ dalam penelitian ini menyatakan bahwa website layout design berpengaruh positif dan signifikan terhadap sikap dapat diterima. Hasil ini menjelaskan bahwa semakin baik tampilan website layout design semakin meningkatkan sikap yang positif konsumen lazada.co.id.

Hasil ini sejalan dengan penelitian terdahulu yang pernah dilakukan oleh Manganari et al. (2014). Dinyatakan bahwa Kemudahan penggunaan tata letak virtual yang dirasakan secara positif signifikan mempengaruhi sikap konsumen terhadap toko online. Kemudian, dalam penelitian lain dinyatakan bahwa desain situs web berhubungan positif signifikan dengan keadaan kognitif konsumen (Yoon, 2014). Penelitian yang dilakukan oleh Lee et al. (2014) juga mendukung bahwa desain tata letak sebuah website memiliki pengaruh yang besar terhadap sikap konsumen online. Hal yang selaras juga diungkapkan bahwa desain situs web di situs merek mewah akan memberi dampak positif signifikan pada sikap terhadap merek (H. Lee et al., 2015).

Pengujian hipotesis ketiga menunjukkan hasil bahwa hubungan antara sikap dengan niat membeli kembali adalah signifikan dengan t-statistik sebesar 3,561 ( $>1,96$ ). Nilai koefisien jalur sebesar 0,4 menunjukkan bahwa arah hubungan antara sikap dengan niat membeli kembali adalah positif. Hipotesis $\mathrm{H}_{3}$ dalam penelitian ini menyatakan bahwa sikap berpengaruh positif dan signifikan terhadap niat membeli kembali dapat diterima. Hasil ini menjelaskan bahwa semakin baik atau positif sikap maka semakin meningkatkan niat membeli kembali konsumen lazada.co.id.

Hasil ini sejalan dengan penelitian terdahulu yang pernah dilakukan oleh Dewi \& Ardani (2016) meningkatnya sikap yang positif signifikan maka akan meningkatkan pula niat beli ulang konsumen, dinyatakan bahwa variabel sikap berpengaruh secara signifikan terhadap niat beli ulang konsumen. Pada penelitian sebelumnya yang dilakukan oleh Mao \& Lyu (2017) sikap memiliki pengaruh positif signifikan pada niat pelanggan untuk membeli kembali melalui situs Airbnb. Hasil penelitian lain juga menyatakan bahwa Semakin tinggi sikap terhadap merek, semakin tinggi pula minat beli ulang konsumen (Hanfan, 2017).

Uji Sobel dilakukan untuk menguji signifikansi pengaruh tidak langsung variabel website layout design $\left(\mathrm{X}_{1}\right)$ terhadap variabel niat membeli kembali $\left(\mathrm{Y}_{2}\right)$ melalui variabel sikap $\left(\mathrm{Y}_{1}\right)$. Uji Sobel dihitung dengan menggunakan aplikasi Microsoft Excel 2016. Nilai koefisien z jika lebih besar dari 1,96, maka variabel sikap sebagai variabel mediasi dalam penelitian ini dinilai secara signifikan mampu memediasi hubungan pengaruh websited layout design terhadap niat membeli kembali.

Hasil Uji Sobel menunjukkan bahwa nilai koefisien z adalah 3,288> 1,96 dengan tingkat signifikansi $0,000<0,05$, sehingga $\mathrm{H}_{0}$ ditolak dan $\mathrm{H}_{1}$ diterima. Hasil tersebut mengartikan bahwa sikap sebagai variabel mediasi dinilai secara signifikan 
mampu memediasi pengaruh website layout design terhadap niat membeli kembali. Hal ini menjelaskan bahwa niat membeli kembali konsumen Lazada.co.id di Bali akan meningkat jika sikap positif meningkat yang dipengaruhi oleh baiknya tampilan website layout design. Selain secara langsung, pengaruh website layout design terhadap niat membeli kembali akan semakin tinggi jika mampu meningkatkan sikap konsumen.

Hipotesis empat merupakan hasil modifikasi dari beberapa jurnal. Walaupun demikian, hasil penelitian ini menyatakan bahwa sikap berpengaruh signifikan dalam memediasi website layout design terhadap niat beli kembali. Hal ini sejalan juga dengan peneliti terdahulu. Hubungan antara website layout design dan sikap memiliki hubungan yang positif signifikan (Manganari et al., 2014 ; Yoon, 2014; H. Lee et al., 2015). Hubungan positif signifikan juga terjadi antara sikap dan niat beli kembali (Dewi \& Ardani, 2016;Mao \& Lyu, 2017; Hanfan, 2017). Sehingga dalam penelitian ini dugaan dalam hipotesis empat atau $\mathrm{H}_{4}$ sebelumnya dapat diterima, yaitu variabel sikap berperan sebagai variabel yang memediasi website layout design dan niat membeli kembali.

Berdasarkan hasil penelitian yang dilakukan menunjukkan bahwa penelitian ini telah mampu mengkonfirmasi beberapa penelitian terdahulu, sekaligus memperkuat penelitian terdahulu mengenai website layout design dan sikap dalam kaitannya dengan niat membeli kembali. Selain itu, peneltian ini memiliki kontribusi implikasi teoritis terkait terbatasnya penelitian yang menjelaskan hubungan secara spesifik website layout design dan niat membeli kembali.

Berdasarkan hasil penelitian ini diharapkan digunakan sebagai masukan dan evaluasi bagi perusahaan lazada.co.id, khususnya kepada bagian pembuat dan pengembang User Experience (UX) di website Lazada.co.id. Sehingga dapat meningkatkan niat membeli kembali dari konsumen dengan memperhatikan website layout design sebagai fokus utamanya. Sebab, dari hasil yang diperoleh, website layout design memiliki pengaruh yang paling besar terhadap niat membeli kembali. Sesuai dengan hasil penelitian ini, indikator yang masih dapat ditingkatkan kembali oleh perusahaan adalah meningkatkan tingkat user-friendly pada website layout design di Lazada.co.id.

Berdasarkan penelitian yang telah dilakukan, ditemukan beberapa keterbatasan dalam penelitian ini. Penelitian ini hanya sebatas meneliti mengenai peran sikap dalam memediasi pengaruh website layout design terhadap niat membeli kembali di provinsi Bali, serta hasil penelitian ini tidak dapat digeneralisir maupun tidak dapat digunakan pada daerah lain maupun pada website lain. Selain itu, penelitian ini hanya sebatas pada konsumen Lazada.co.id di provinsi Bali, dalam lingkup yang relatif kecil, dengan pengambilan data secara cross section sehingga dapat menimbulkan hasil yang berbeda jika terdapat penelitian serupa di waktu yang berbeda. Keterbatasan lainnya adalah masih sedikitnya penelitian yang menjelaskan hubungan secara spesifik antara website layout design dan niat membeli kembali, serta hubungan secara spesifik yang menjelaskan variabel sikap sebagai variabel mediasi antara website layout design dan niat membeli kembali. 


\section{SIMPULAN}

Berdasarkan tujuan penelitian, rumusan masalah dan hasil penelitian dengan pembahasan yang telah dipaparkan sebelumnya, maka dapat diambil kesimpulan yaitu website layout design berpangaruh positif dan signifikan terhadap sikap konsumen lazada.co.id. Hasil ini menjelaskan bahwa semakin baik tampilan website layout design semakin meningkatkan sikap yang positif konsumen lazada.co.id. Website layout design berpengaruh positif dan signifikan terhadap niat membeli kembali konsumen Lazada.co.id. Hasil ini menunjukkan bahwa semakin baik tampilan website layout design semakin meningkatkan niat membeli kembali konsumen lazada.co.id. Sikap berpengaruh positif dan signifikan terhadap niat membeli kembali konsumen lazada.co.id. Hasil ini menjelaskan bahwa semakin baik atau positif sikap maka semakin meningkatkan niat membeli kembali konsumen lazada.co.id.

Sikap mampu memediasi website layout design dan niat membeli kembali. Hal ini menunjukkan bahwa niat membeli kembali konsumen Lazada.co.id di Bali akan meningkat jika sikap positif meningkat yang dipengaruhi oleh baiknya tampilan website layout design. Peran sikap sebagai mediator dalam menghubungkan website layout design dan niat membeli kembali bersifat parsial. Hal tersebut disebabkan oleh niat membeli kembali dapat dipengaruhi langsung oleh variabel website layout design. Berdasarkan hasil dari penelitian yang telah dilakukan, menunjukkan bahwa website layout design memiliki pengaruh yang sangat tinggi jika dibandingkan dengan pengaruh sikap secara langsung ataupun sikap yang berperan sebagai variabel mediasi terhadap niat membeli kembali. Maka dari itu bagi Lazada.co.id, diharapkan dapat selalu berupaya untuk meningkatkan kualitas tampilan website layout design.

Deskripsi data hasil penelitian menunjukkan rata-rata yang baik, sehingga diharapkan perusahaan mampu mengelola kembali agar menjadi lebih baik kedepannya. Di samping itu, berdasarkan data yang diperoleh dari sejumlah 90 responden, terdapat satu indikator yang masih perlu ditingkatkan yaitu tentang indikator meningkatkan tingkat user-friendly pada website layout design di Lazada.co.id yang harapannya dapat meningkatkan niat konsumen untuk kembali membeli melakukan pembelian di Lazada.co.id. Bagi peneliti selanjutnya, diharapkan agar dapat melakukan penelitian serupa yang menyatakan hubungan antara website layout design dan niat kembali. Hal tersebut dikarenakan masih sedikitnya penelitian yang menjelaskan hubungan tersebut. Serta hubungan secara spesifik yang menjelaskan variabel sikap sebagai variabel mediasi antara website layout design dan niat membeli kembali.

\section{REFERENSI}

Adinata, K. J., \& Yasa, N. N. K. (2018). Pengaruh Kepercayaan, Persepsi Harga, Dan Sikap Terhadap Niat Beli Kembali Di Situs Lazada. E-Jurnal Manajemen Universitas Udayana, 7(8), 2302-8912. https://doi.org/doi.org/10.24843/EJMUNUD.2018.v07.i08.p05

Alam, K., \& Adam, M. (2017). Pengaruh Persepsi Informasi Dan Hiburan Terhadap Niat Pembelian Konsumen Dengan Kepercayaan Pada Situs Web 
Sebagai Mediasi (Studi Pada Konsumen Lazada.co.id Di Fakultas Ekonomi Dan Bisnis Universitas Syiah Kuala Banda Aceh). Jurnal Ilmiah Mahasiswa Ekonomi Manajemen, 2(1), 156-169. Retrieved from http://www.jim.unsyiah.ac.id/EKM/article/view/3581

Anggraeny, V., Huffron, M., \& Slamet, A. R. (2018). Pengaruh Discount dan Elemen-Elemen Store Atmosphere Terhadap Impulse Buying. E-Jurnal Riset Manajemen, 7(3), 133-142.

Bitner, M. J. (2015). The Effects of Information Format and Shopping Task on Consumer's Online Shopping Behavior: A Cognitive Fit Perspective. Journal of Management Information System, 56(2), 57-71.

Chiu, C. M., Chang, C. C., Cheng, H. L., \& Fang, Y. H. (2014). Determinants of Customer Repurchase Intention in Online Shopping. Online Information Review, 33(4), 761-784.

Dewi, N. P. R. A., \& Ardani, I. G. A. K. S. (2016). Pengaruh Sikap Dan Norma Subjektif Terhadap Niat Beli Ulang Produk Fashion Via Online Di Kota Denpasar. E-Jurnal Manajemen Universitas Udayana, 5(4), 2637-2664.

Dwipayana, B., \& Sulistyawati, E. (2018). Peran Kepuasan Dalam Memediasi Pengaruh Kepercayaan Terhadap Niat Beli Ulang Pada Go-Food Di FEB UNUD. E-Jurnal Manajemen Universitas Udayana, 7(10), 5197-5229. https://doi.org/doi.org/10.24843/EJMUNUD.2018.v07.i06.p01

Hanfan, A. (2017). Mengeksplorasi Kesadaran Merek Terhadap Minat Beli Ulang Melalui Sikap Terhadap Merek. Sustainable Competitive Advantage, 7(1), 61-73.

Hasan, L., \& Abuelrub, E. (2014). Assessing The Quality Of Web Sites. Applied Computing and Informatics, 9(11), 2210-8327. https://doi.org/doi.org/10.1016/j.aci.2009.03.001

Hernandhi, D. T., Astuti, E. S., \& Priambada, S. (2018). Desain Sistem Informasi Pemasaran Berbasis Website Untuk Promosi (Studi Kasus Pada Kedai Ayam Geprak \& Sambal Bawang Malang). Jurnal Administrasi Bisnis, 5(1), 1-10.

Hong, W., James, Y. . T., \& Karyantam, T. (2014). The Effects of Information Format and Shopping Task on Consumer's Online Shopping Behavior: A Cognitive Fit Perspective. Journal of Management Information System, 21(3), 149-184.

Idris, A. D. M. (2017). Pengaruh Faktor Atribut Produk, Persepsi Nilai, Dan Pengalaman Konsumen Terhadap Minat Beli Ulang Yang Dimediasi Oleh Kepuasan Konsumen (Pada Pengguna Apple Iphone Di Semarang). Diponegoro Journal of Management, 6(4), 1-9.

Kashif, A., Zaman, S., \& Satti, W. (2017). Impact of Online Store Atmosphere, Customized Information and Customer Satisfaction on Online Repurchase Intention. GMJACS, 7(2), 22-34. 
Lee, C.-L., Lee, F. C.-S., \& Hong-Chun, W. (2014). How Can Online Store Layout Design And Atmosphere Influence Consumer Shopping Intention On A Website? International Journal of Retail \& Distribution Management, 42(1), 4-24. https://doi.org/https://doi.org/10.1108/IJRDM-01-2013-0035

Lee, H., Kim, Y., \& Jung, C. Y. (2015). Web Atmospheric Qualities In Luxury Fashion Brand Websites. Journal Of Fashion Marketing and Management, 19(4), 384-401. https://doi.org/https://doi.org/10.1108/JFMM-09-2013-0103

Lloyd, C. H., \& Goode, M. M. H. (2014). Online Services Capes, Trust, And Purchase Intentions. Journal of Services Marketing, 24(3), 230-243.

Madhavaiah, I. B. C. (2015). Consumer Attitude And Behavioural Intention Towards Internet Banking Adoption In India. Journal of Indian Business Research, 7(1), 67-102. https://doi.org/https://doi.org/10.1108/JIBR-022014-0013

Manganari, E. E., Siomkos, G. J., Rigopoulou, I. D., P., A., \& Vrechopoulos. (2014). Virtual Store Layout Effects On Consumer Behaviour Applying An Environmental Psychology Approach In The Online Travel Industry. Internet Research, 21(3), 326-346.

Mao, Z., \& Lyu, J. (2017). Why travelers use Airbnb again?: An integrative approach to understanding travelers' repurchase intention. International Journal of Contemporary Hospitality Management, 29(2), 2464-2482.

Megantara, I. M. T., \& Suryani, A. (2016). Penentu Niat Pembelian Kembali Tiket Pesawat Secara Online Pada Situs Traveloka.com. E-Jurnal Manajemen Universitas Udayana, 5(9), 5783-5810.

Nazirah, U., \& Sorayanti., U. (2017). Pengaruh Kualitas Desain Website Terhadap Niat Pembelian Dimediasi Oleh Persepsi Kualitas Produk Pada Lazada.co.id. Jurnal Ilmiah Mahasiswa Ekonomi Manajemen, 2(3), 55-69.

Putra, F. W., \& Sulistyawati, E. (2018). Peran Kepuasan Pelanggan dalam Memediasi Pengaruh Kuliatas Layanan Terhadap Loyalitas Pelanggan. EJurnal Manajemen Unud, 7(1), 525-554.

Sandy, C. C., \& Dhillon, G. S. (2017). Interpreting Dimensions of Consumer Trust in E-commerce. Information Technology and Management, 4(1), 303-318.

Sany, S., Anandya, D., \& Honantha, C. R. (2014). Pengaruh Store Layout dan Atmosphere Terhadap Shopping Intention Zalora Online Store. Jurnal Manajemen Teori Dan Terapan Universitas Surabaya, 7(1), 13-21. https://doi.org/http://dx.doi.org/10.20473/jmtt.V7I1.\%25p

Sari, I., Nobelson, D. P. ., \& Sembiring, R. (2017). Pengaruh Harga (Price), Kenyamanan Konsumen (Customer Convenience) dan Kepercayaan (Trust) Terhadap Minat Beli Di Lazada.co.id. ISEI Business and Management Review, 1(2), 73-78. 
E-Jurnal Manajemen, Vol. 9, No. 2, 2020 : 446-465

Sugiyono. (2017). Metode Penelitian Kuantitatif, Kualitatif, dan R\&D. Bandung: Alfabeta.

Thomas, M. R., Kavya, V., \& Monica, M. (2018). Online Website Cues Influencing The Purchase Intention Of Generation Z Mediated By Trust. Indian Journal of Commerce and Management Studies, 9(1), 13-23. https://doi.org/http://dx.doi.org/10.18843/ijcms/v9i1/03

Yoon, E. (2014). Effects of Website Environmental Cues on Consumers' Response and Outcome Behaviors. Education and Human Sciences, 1(1), 1-20.

Zhang, Y., Fang, Y., Wei, K.-K., Ramsey, E., McCole, P., \& Chen, H. (2014). Repurchase Intention In B2C E-commerce-A Relationship Quality Perspective. Information \& Management, 48(1), 192-200. 